\title{
SISTEM INFORMASI KEPEGAWAIAN BERBASIS WEB PADA UNIT PELAKSANA TEKNIS (UPT) PUSKESMAS KECAMATAN UNTER IWES
}

\author{
${ }^{1)}$ Haerun Nisa, ${ }^{2}$ Shinta Esabella, ${ }^{3)}$ Rodianto \\ ${ }^{1), 2), 3)}$ Program Studi Teknik Informatika Universitas Teknologi Sumbawa \\ 1)annisa28nisa@gmail.com, ${ }^{2)}$ sesabella@gmail.com, ${ }^{3)}$ rodianto.mursali@gmail.com
}

\begin{abstract}
ABSTRAK
Tujuan penelitian ini adalah untuk membangun sistem informasi yang berkaitan dengan pengelolaan data dan informasi kepegawaian pada UPT Puskesmas Unter Iwes. Adapun metode dalam penelitian menggunakan metode studi lapangan dengan metode waterfall sebagai metode pengembangan sistemnya. Sistem berbasis web ini dibangun dengan bahasa pemrograman PHP (Hypertext Preprocessor) dan MySQL sebagai Database Management System (DBMS). Dalam Sistem Informasi Kepegawaian ini terdapat data pribadi pegawai, data pangkat dan data jabatan yang dikelola secara terkomputerisasi. Dengan adanya Sistem informasi kepegawaian dapat mempermudah admin bagian administrasi kepegawaian dalam mengelola data dan informasi yang menyangkut pengelolahan data kepegawaian pada UPT Puskesmas Unter Iwes.
\end{abstract}

Kata Kunci: Sistem Informasi, Kepegawaian, Puskesmas

\section{PENDAhUluan}

Perkembangan teknologi informasi dan komunikasi pada zaman modern ini telah banyak memeberikan perubahan dalam kehidupan manusia. Peranan teknologi informasi dan komunikasi memberikan kemudahan bagi manusia untuk mengerjakan pekerjaannya, baik itu di bidang komunikasi, bisnis, hiburan, ekonomi maupun kesehatan.

Unit Pelaksana Teknis (UPT) Puskesmas Kecamatan Unter Iwes Kabupaten Sumbawa merupakan salah satu unit jasa pelayanan dalam bidang kesehatan yang berada di Kelurahan Kerato, Kecamatan Unter Iwes. Selain pelayanan kesehatan kepada masyarakat yang menjadi faktor terpenting dari UPT Puskesmas Kecamatan Unter Iwes, terdapat juga pelayanan lainnya seperti pelayanan puskesmas terhadap pegawainya. Dalam sistem pelayanan yang ada di UPT Puskesmas Kecamatan Unter Iwes kepada pegawainya saat ini masih dirasakan kurang maksimal, dimana sistem kepegawaian yang ada masih bersifat manual. Sebagai contoh data-data mengenai kepegawaian diolah dengan menggunakan software aplikasi perkantoran yaitu berupa Microsoft word dan excel, adapun proses pencarian data seorang pegawai atau informasi mengenai data riwayat pangkat serta jabatan dari pegawai tersebut diolah secara manual. Dengan sistem yang masih manual tersebut membuat sulitnya karyawan untuk mengetahui data dan informasi pegawai yang ada didalam lingkungan UPT Puskesmas Unter Iwes.

Berdasarkan masalah tersebut, peneliti mencoba membangun Sistem Informasi Kepegawaian berbasis Web pada UPT Puskesmas Unter Iwes.

Diharapkan dengan system informasi yang dibangun dapat mempermudah UPT Puskesmas Unter Iwes dalam mengelola data dan informasi kepegawaiannya.

\section{METODOLOGI}

Metode perancangan sistem dalam penelitian ini menggunakan metode Waterfall yang merupakan model klasik yang bersifat sistematis, berurutan dalam membangun sebuah Sistem Informasi.

Adapun langkah yang digunakan dalam membangun Sistem Informasi Kepegawaian Berbasis Web di UPT Puskesms Kecamatan Unter Iwes adalah sebagai berikut:

\section{Analysis}

Pada tahap ini, penulis menganalisa kebutuhan Sistem Informasi yang akan dibangun. Penulis mengumpulkan data-data sebagai bahan perancangan sistem Informasi.Pengumpulan data yang dilakukan adalah dengan menggunakan teknik observasi, wawancara dan studi pustaka pada bagian administrasi kepegawaian di UPT Puskesmas Kecamatan Unter Iwes.

2. Design 
Pada tahap ini dilakukan penterjemahan analisa kebutuhan ke dalam bentuk rancangan sebelum penulisan program yang bertujuan untuk mengatasi permasalahan yang ada. Adapun tahapan yang digunakan pada tahap design menggunakan perancangan terstruktur dengan menggunakan Diagram Kontek, Data Flow Diagram, Entity Relationship Diagram dan perancangan Database serta tampilan antar muka untuk memudahkan dalamproses pengkodean.

3. Code

Tahap mentrasformasikan designkedalam baris-baris program yaitu dengan menggunakan bahasa pemrograman Hypertext Preprocessor (PHP).

4. Test

Pada tahap ini dilakukan uji coba pada web Sistem Informasi Kepegawaian di UPT Puskesmas Kecamatan Unter Iwes yang telah dibuat. Proses uji coba ini diperlukan untuk memastikan web tersebut sudah berjalan sesuai dengan karakteristik yang diterapkan dan di harapkan.

\section{HASIL DAN PEMBAHASAN}

Dengan menggunakan metode Waterfall dalam penelitian ini, maka proses yang dilakukan dalam membangun Sistem Informasi Kepegawaian Berbasis Webdi UPT Puskesmas Kecamatan Unter Iwes adalah sebagai berikut:

\section{Analisis}

Merupakan tahap permulaan dalam pembentukan kebutuhan dari semua elemen sistem dan menganalisis kebutuhan yang diinginkan dari UPT Puskesmas Kecamatan Unter Iwes khususnya pada bagian administrasi kepegawaian, dimana pada tahapini penulis melakukan komunikasi dengan staff dan kepala Sub Bagian Administrasi Kepegawaian di UPT Kecamatan Unter Iwes. Berikut adalah hasil analisis kebutuhan dalam penelitian ini :

1. Kebutuhan Data

Adapun kebutuhan data yang didapatkan berupa data dan informasi yang bersumber antara lain:

Tabel 3.1 Kebutuhan Data Sumber Data dan Informasi

Kepala Subbag Administrasi Menginginkan Sistem Informasi Kepegawaian dari pegawai kepada
UPT Puskesmas

bagian Kepegawaian

Kecamatan Unter

berbasis web

Iwes

Staff atau admin

Format Formulir

subbag

administrasi

Kepegawaian

pangkat dan data jabatan pegawai.

2. Kebutuhan Perangkat Keras

Kebutuhan perangkat keras dalam penelitian ini adalah sebagai berikut :

Tabel 3.2 Spesifikasi Perangkat Keras

\begin{tabular}{|l|l|l|}
\hline No & $\begin{array}{c}\text { Perangkat } \\
\text { keras }\end{array}$ & \multicolumn{1}{|c|}{ Keterangan } \\
\hline 1. & Laptop & - Processor Intel (R) \\
& & Celeron (R) CPU \\
& & $1007 \mathrm{U}$ @ 1,50Ghz \\
& & $1.150 \mathrm{Ghz}$ \\
& & - RAM 4.00 GB \\
& & - Harddisk 500 GB \\
& & - VGA Intel HD \\
& & Grapichs \\
\hline
\end{tabular}

3. Kebutuhan Perangkat Lunak

Kebutuhan Perangkat Lunak dalam

Penelitian ini adalah sebagai berikut :

Tabel 3.3 Spesifikasi Perangkat Lunak

\begin{tabular}{|l|l|l|}
\hline No & \multicolumn{1}{|c|}{$\begin{array}{c}\text { Perangkat } \\
\text { Lunak }\end{array}$} & \multicolumn{1}{|c|}{ keterangan } \\
\hline 1. & $\begin{array}{l}\text { Sistem untuk } \\
\text { menjalankan } \\
\text { program }\end{array}$ & $\begin{array}{l}\text { Windows7 } \\
\text { Professional }\end{array}$ \\
\hline 2. & $\begin{array}{l}\text { Pemrograman } \\
\text { Web }\end{array}$ & PHP versi 5.5 \\
\hline 3. & $\begin{array}{l}\text { Pengelolah } \\
\text { basisdata }\end{array}$ & MySQL versi 5.6.17 \\
\hline 4. & Web Editor & Sublime Text 3 \\
\hline 5. & Web server & Xampp versi 1.8.3 \\
\hline 6. & Web browser & Mozilla Firefox \\
\hline
\end{tabular}

2. Design

Pada tahap ini dilakukan proses perancangan, yang bertujuan untuk memberikan gambaran apa yang seharusnya dikerjakan dan bagaimana tampilannya. Dalamtahap ini menggunakan perancangan terstruktur untuk memudahkan dalam proses membangun Sistem Informasi Kepegawaian di UPT Puskesmas Kecamatan Unter Iwes. 
Diagram Konteks

Diagram konteks merupakan diagram yang menggambarkan sistem sebagai sebuah proses. Tujuannya adalah memberikan gambaran umum pada sistem. Berikut adalah gambar Diagram Konteks dalam Sistem Informasi Kepegawaian Berbasis Web di UPT Puskesmas Kecamatan Unter Iwes adalah sebagai berikut :

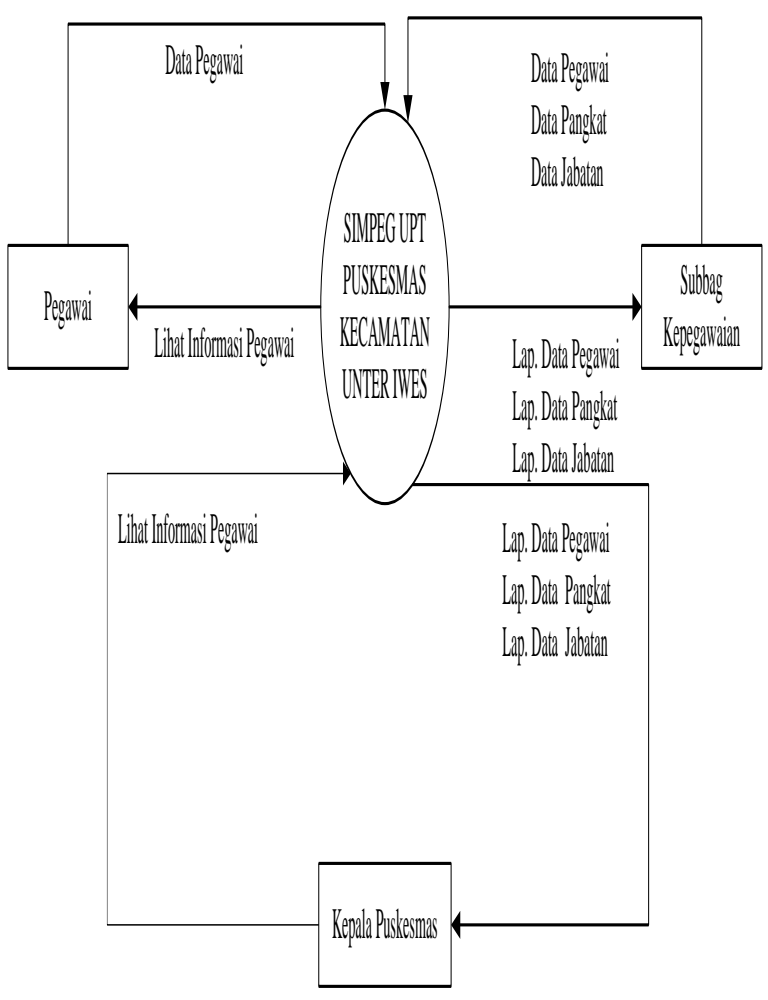

Gambar 3.1 Diagram Konteks

Dari gambar diagram konteks tersebut, sistem Informasi Kepegawaian akan mengelolah data mengenai data pribadi pegawai, data pangkat dan data jabatan. Data yang telah diolah akan dilaporkan kepada Kepala Puskesmas.

\section{Data Flow Diagram (DFD)}

Data Flow Diagram (DFD) adalah alat bantu dalam pembuatan model proses yang digunakan untuk menggambarkan sistem. Gambar DFD Level 0 pada Sistem Informasi Kepegawaian di UPT Puskesmas Kecamatan Unter Iwes adalah sebagai berikut :

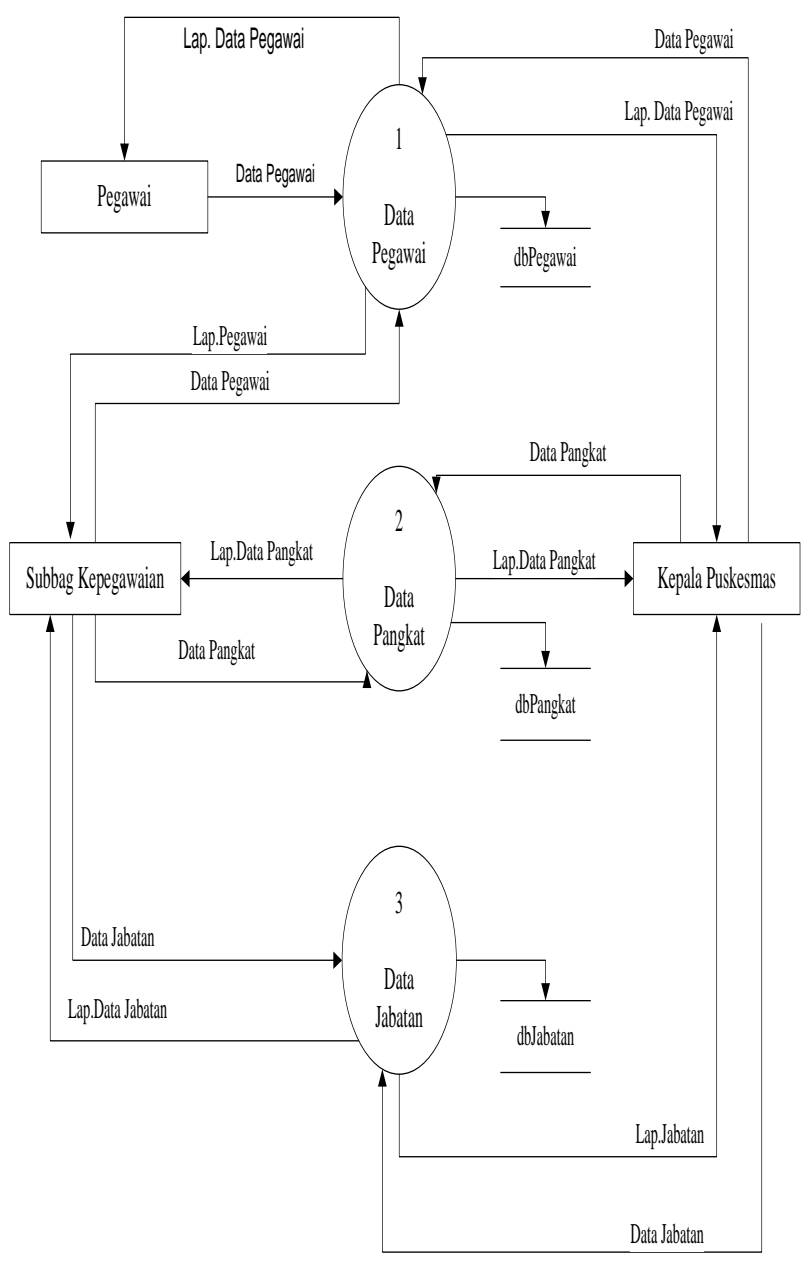

Gambar 3.2 DFD Level 0

Entity Relationship Diagram (ERD)

Entity Relationship Diagram (ERD) merupakan tools yang digunakan untukmemodelkan struktur data dengan menggambarkan entitas dan hubungan antara entitas atau relationship secara abstrakdan konseptual. Berikut Entity Relationship Diagram (ERD) dalam sistem Informasi Kepegawaian di UPT Puskesmas Kecamatan Unter Iwes : 


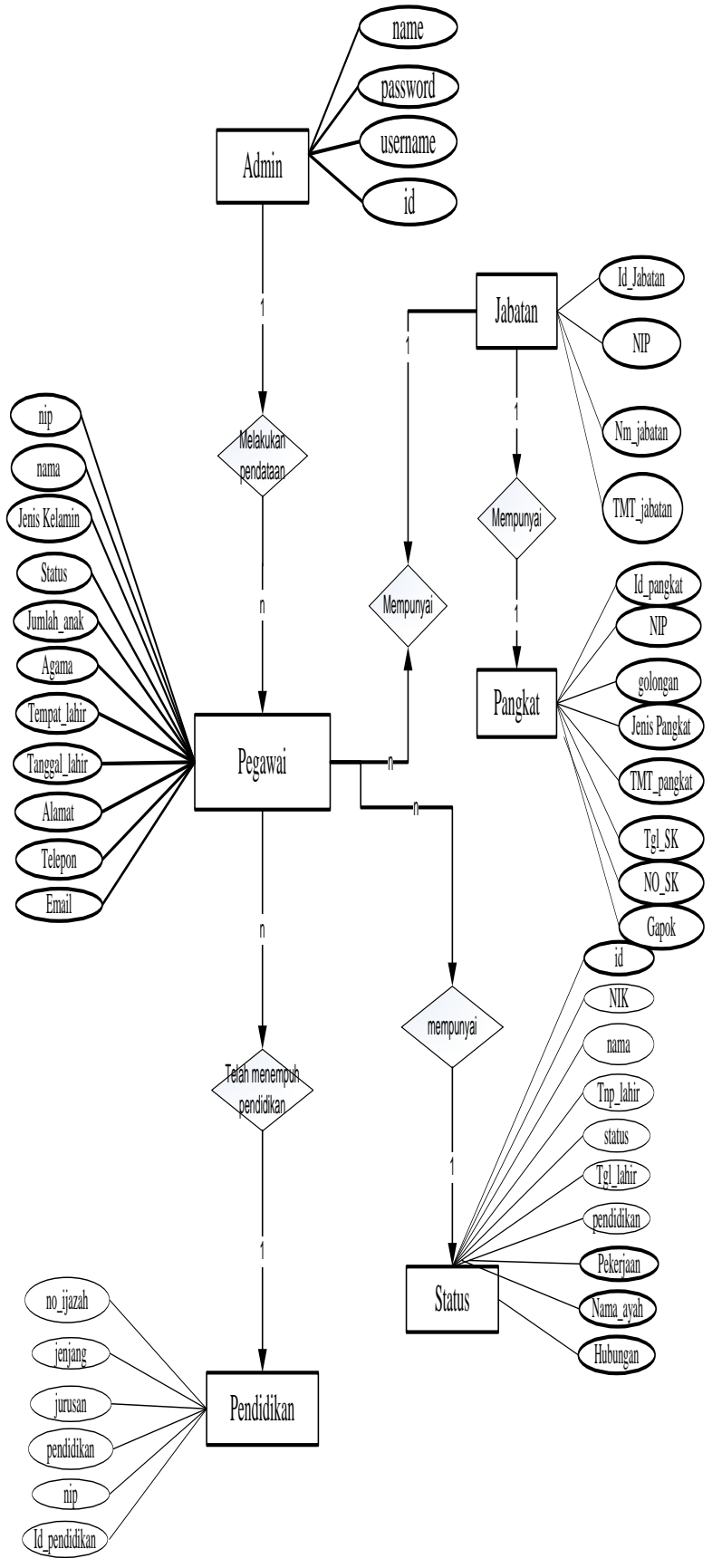

Gambar 3.3Entity Relationship Diagram

Perancangan Basis Data

Rancangan basis data pada Sistem Informasi Kepegawaian di UPT Puskesmas Kecamatan Unter Iwes meliputi beberapa tabel basis data yang mendukung operasi dan tujuan Sistem Informasi. Adapun basis data yang digunakan adalah sebagai berikut:

1) File Data Admin

Nama File : Admin

Kunci File : id
Keterangan : Digunakan untuk menyimpan username dan password admin yang akan mengakses SistemInformasi Kepegawaian.

Tabel 3.4 File Data Admin

\begin{tabular}{|c|c|c|c|c|}
\hline Field_Name & Type & Size & Key & Description \\
\hline id & Int & 11 & PRI & Id User \\
\hline usemame & varchar & 50 & & Username \\
\hline password & yarchar & 50 & & Password \\
\hline name & varchar & 50 & & Nama pengguna \\
\hline
\end{tabular}

2) File Data Pegawai

Nama File : Pegawai

Kunci File : NIP

Keterangan : Digunakan untuk menyimpan data pribadi pegawai Puskesmas.

Tabel 3.5 Pegawai

\begin{tabular}{|c|c|c|c|c|}
\hline Field & Type & Size & Key & Description \\
\hline NIP & Varchar & 20 & PRI & NIP Pegawai \\
\hline Nama & Varchar & 50 & & $\begin{array}{c}\text { Nama } \\
\text { Pegawai }\end{array}$ \\
\hline Ins_kelamin & $\begin{array}{c}\text { enum(' }{ }^{\prime} \text { ', } \\
\text { 'P') }\end{array}$ & & & Tenis kelamin \\
\hline $\begin{array}{c}\text { Status } \\
\text { pemikahan }\end{array}$ & Varchar & 15 & & $\begin{array}{c}\text { Sttaus } \\
\text { Pemikahan }\end{array}$ \\
\hline $\begin{array}{c}\text { Status_kepegawai } \\
\text { an }\end{array}$ & Varchar & 20 & & $\begin{array}{c}\text { Status } \\
\text { kepegawaian }\end{array}$ \\
\hline Agama & Varchar & 20 & & Agama \\
\hline Tmpt_lahir & Varchar & 35 & & Tempat_lahir \\
\hline Tgl_lahir & Date & 50 & & Tanggal_lahir \\
\hline Alamat & Varchar & 50 & Alamat \\
\hline Telepon & Varchar & 12 & & Telepon \\
\hline Email & Varchar & 35 & & Email \\
\hline
\end{tabular}

3 3) File Data Status

Nama File : Status

Kunci File : id

Keterangan : Digunakan untuk menyimpan status Pegawai

Tabel 3.6 Tabel Status 


\begin{tabular}{|c|c|c|c|c|}
\hline Field & Type & \begin{tabular}{|l|} 
Size \\
\end{tabular} & Key & Description \\
\hline Id & Int & 11 & PRI & $\begin{array}{c}\text { Id suami// } \\
\text { istri }\end{array}$ \\
\hline NIK & Varchar & 30 & & $\begin{array}{l}\text { NIK Suami } / \\
\text { Istri }\end{array}$ \\
\hline Nama & Varchar & 50 & & $\begin{array}{c}\text { Nama Suami } \\
\text { / Istri }\end{array}$ \\
\hline tmpt lahir & Yarchar & 50 & & TempatLahin \\
\hline tgl_ahir & date & 20 & & $\begin{array}{l}\text { Tanggal } \\
\text { Lahir }\end{array}$ \\
\hline pendidikan & Varchar & 25 & & Pendidikan \\
\hline Pekejaan & Varchar & 20 & & Pekerjaan \\
\hline Hubungan & enum('suami', 'Istri') & & & Hubungan \\
\hline
\end{tabular}

Keterangan : Digunakan untuk menyimpan data pendidikan pegawai.

Tabel 3.9 Data Pendidikan

\begin{tabular}{|c|c|c|c|c|}
\hline Field & Type & Size & Key & Description \\
\hline id_pendidikan & Int & 10 & PRI & $\begin{array}{c}\text { IdPendidikan } \\
\text { Pegawai }\end{array}$ \\
\hline NIP & Varchar & 20 & & NIP \\
\hline pendidikan & Varchar & 30 & & Pendidikan \\
\hline jurusan & Varchar & 25 & & Jusnusan \\
\hline jenjang & Varchar & 15 & & Jenjang \\
\hline no jiazah & Varchar & 30 & & No Jjazah \\
\hline
\end{tabular}

4) File Data Pangkat

Nama File : Pangkat

Kunci File : id_pangkat

Keterangan : Digunakan untuk menyimpan data pangkat pegawai Puskesmas.

Tabel 3.7 Data Pangkat

\begin{tabular}{|c|c|c|c|c|}
\hline Field & Type & Size & Key & Description \\
\hline Id_pangkat & Int & 11 & PRI & $\begin{array}{c}\text { Id_pangkat } \\
\text { Pegawai }\end{array}$ \\
\hline NIP & Yarchar & 20 & MUL & NIP Pegarai \\
\hline Golongan & Yarchar & 20 & & Golongan \\
\hline Ienis_pangkat & Yarchar & 30 & & Lenis Pangkat \\
\hline IMT__pangkat & Date & & & TMT Pangkat \\
\hline Tgl_pengesahan_SK & Date & & & $\begin{array}{c}\text { Tanggal } \\
\text { Pengesahan SK }\end{array}$ \\
\hline No SK & Yarchar & 30 & & No SK \\
\hline Gapok & Varchar & 30 & & $\begin{array}{c}\text { Gaji Pokok } \\
\text { Pegawai }\end{array}$ \\
\hline
\end{tabular}

5) File Data Jabatan

Nama File :Jabatan

Kunci File : id_jabatan

Keterangan : Digunakan untuk menyimpan data jabatan pegawai

Puskesmas.

Tabel 3.8 Data Jabatan

\begin{tabular}{|c|c|c|c|c|}
\hline Field & Type & Size & Key & Description \\
\hline id jabatan & Int & 20 & PRI & $\begin{array}{c}\text { Id Jabatan } \\
\text { Pegawai }\end{array}$ \\
\hline NIP & Yarchar & 20 & MUL & NIP Pegawai \\
\hline nama jabatan & Varchar & 30 & & $\begin{array}{c}\text { Nama } \\
\text { Jabatan }\end{array}$ \\
\hline TMT jabatan & Yarchar & 30 & & TMT Jabatan \\
\hline
\end{tabular}

Perancangan Antar Muka

Merupakan proses merancang interface dari sistem yang akan dibangun. Berikut ini penjabaran tentang rancangan user interface dari Sistem Informasi Kepegawaian di UPT Puskesmas kecamatan Unter Iwes adalah sebagai berikut.

Rancangan Tampilan Login Admin

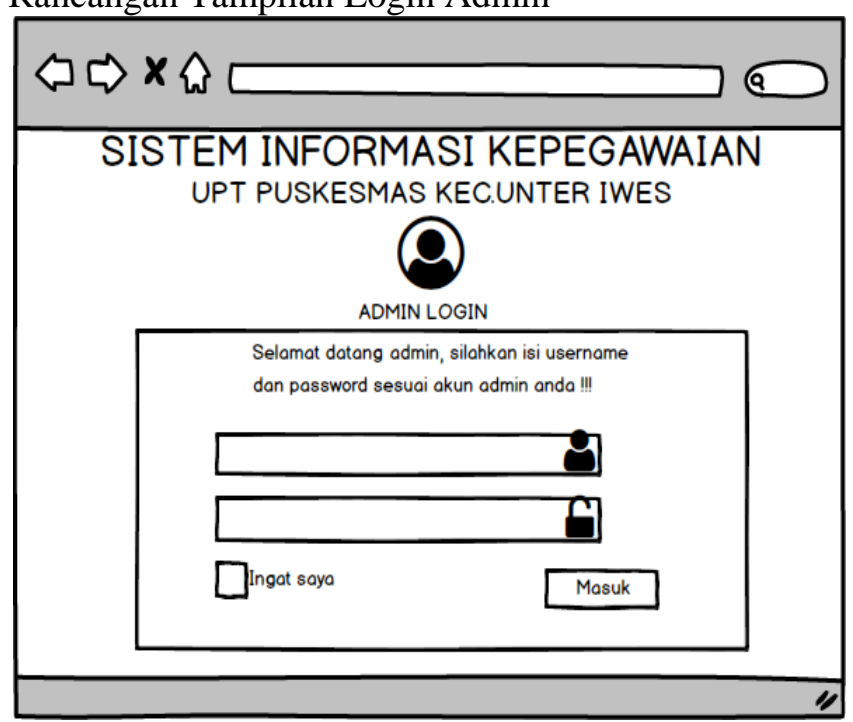

Gambar 3.4 Tampilan Login Admin

Dari gambar diatas pada tampilan Login Admin, admin untuk dapat masuk ke dalam sistem harus memiliki hak akses yaitu harus memiliki username dan password yang telah di sediakan.

Rancangan Tampilan Halaman Dashboard

6) File Data Pendidikan

Nama File :pendidikan

Kunci File : id_pendidikan 


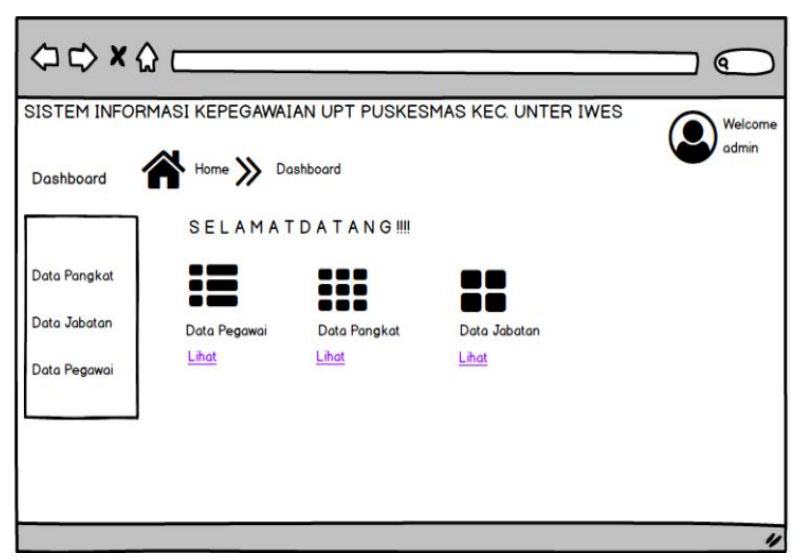

Gambar 3.5 Rancangan Halaman Dashboard Dari gambar diatas, tampilan dashboard merupakan halaman pertamayang munculketika admin melakukan login dengan benar. Pada halaman ini kan menampilkan beberapa menu dalam mengakses dan mengelolah data kepegawaian

Rancangan Halaman Tampilan Tabel Data Pegawai

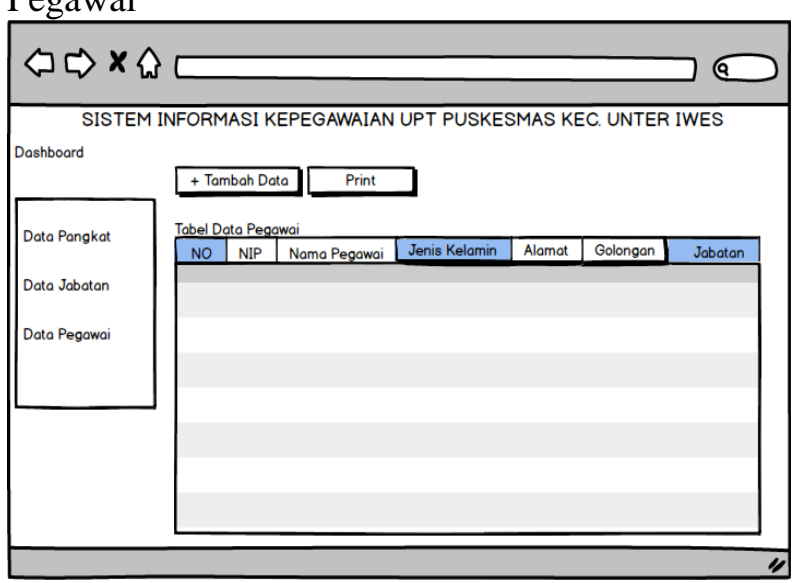

Gambar 3.6 Rancangan Halaman Tampilan Tabel Data Pegawai

Tampilan data tabel pegawai terdapat tabel NIP,nama pegawai, jenis kelamin, alamat dan golongan. Pada tabel data pegawai terdapat button tambah data dan button print.Button tambah data berfungsi untuk menambah data terbaru dari setiap pegawai yang ada di UPT Puskesmas Kecamatan Unter Iwes. Button tentang print berfungsi untuk mencetak tabel dari data pegawai yang telah di isi sebelumnya.

Rancangan Tampilan Halaman Tambah data Pegawai

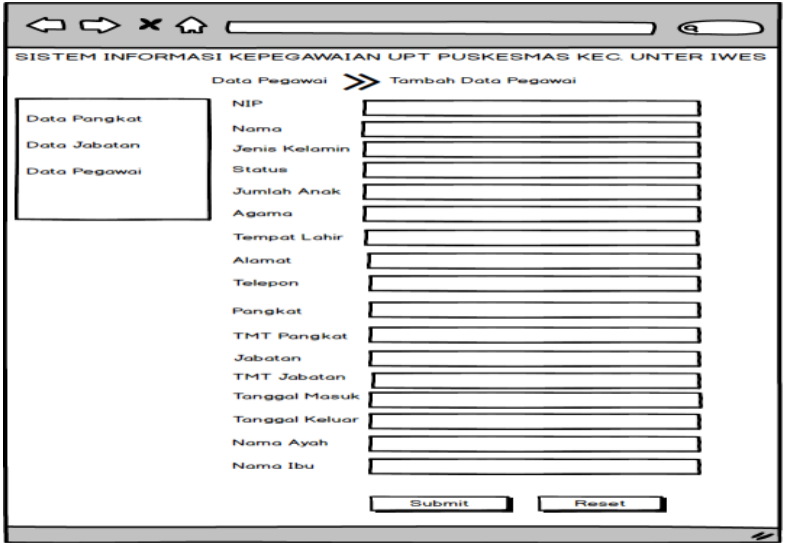

Gambar 3.7Rancangan Tambah Data Pegawai

Rancangan tampilan tambah data pegawai akan menampilkan form tambah data pegawai yang baru di Sistem Informasi kepegawaian.

Rancangan Halaman Tampilan Tabel Data Pangkat

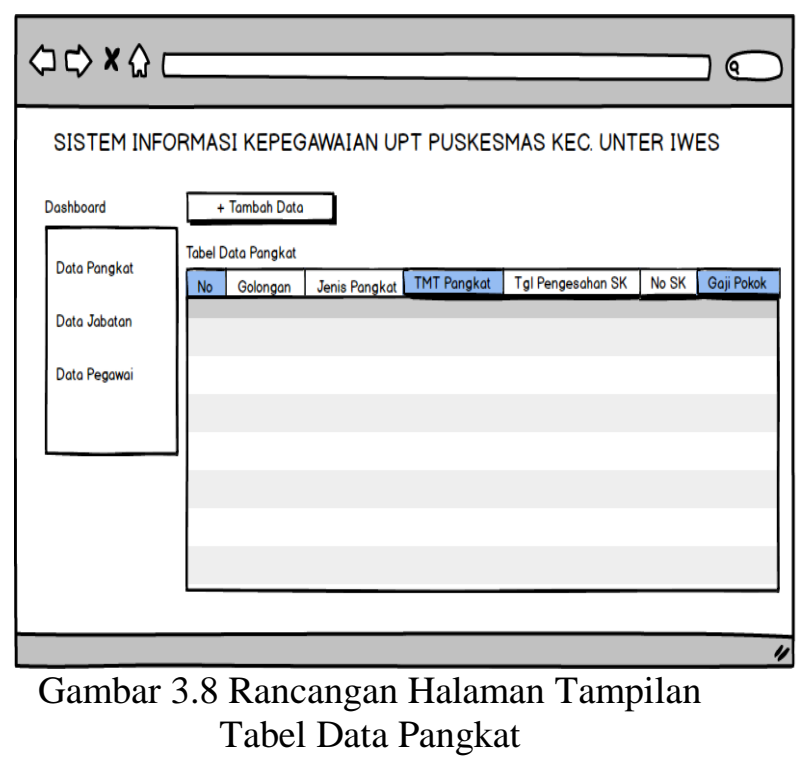

Pada tampilan tabel data pangkat yaitu akan menampilkan daftar pangkat pegawai. Pada form data pangkat. Admin dapat menambah pangkat dari seorang pegawai yang ada di UPT Puskesmas Kecamatan Unter Iwes.

Rancangan Halaman Tampilan Tambah Data Pangkat 


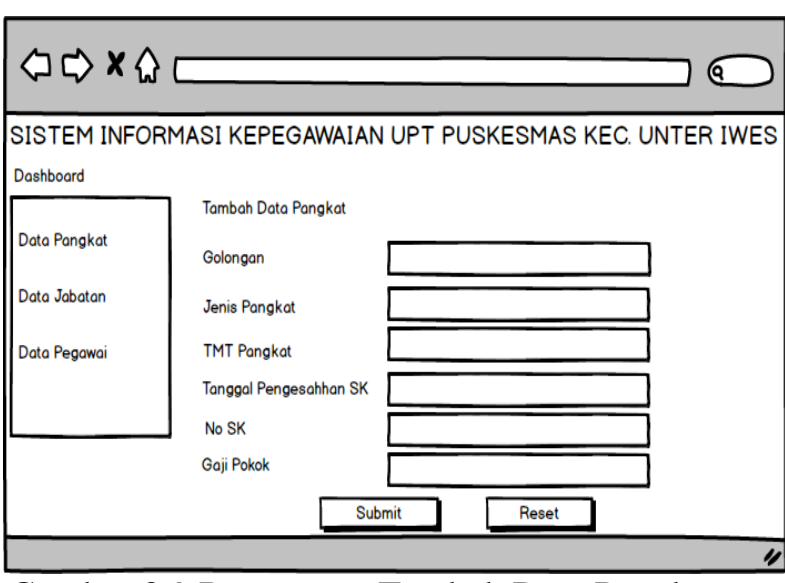

Gambar 3.9 Rancangan Tambah Data Pangkat

yaitu rancangan tampilan tambah data pangkat akan menampilkan form tambah data pangkat pegawai.

Rancangan Halaman Tampilan Tabel Data Jabatan

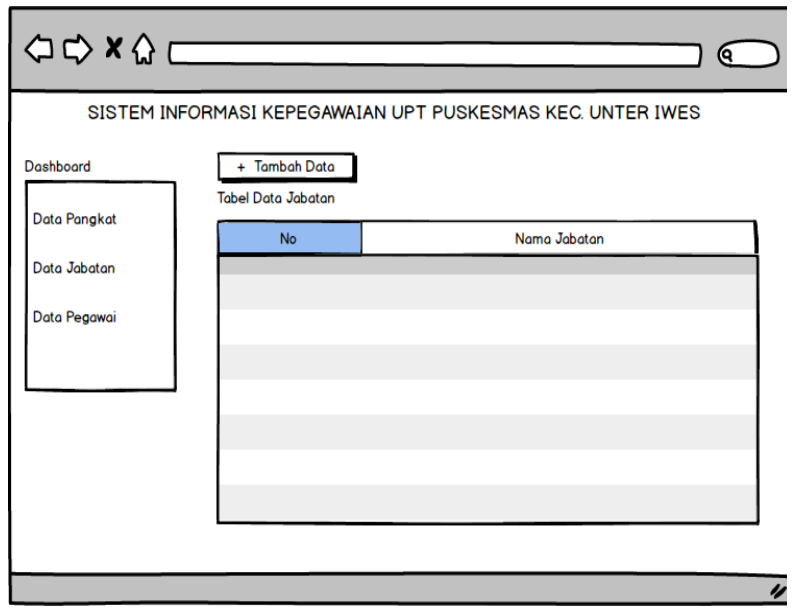

Gambar 3.10 Rancangan Halaman Tampilan Tabel Data Jabatan

Pada rancangan tampilan data jabatan pegawai, data jabatan akan menampilkan daftar pegawai yang telah mengalami perubahan jabatan dari jabatan sebelumnya.

Rancangan Halaman Tampilan Tambah Data Jabatan

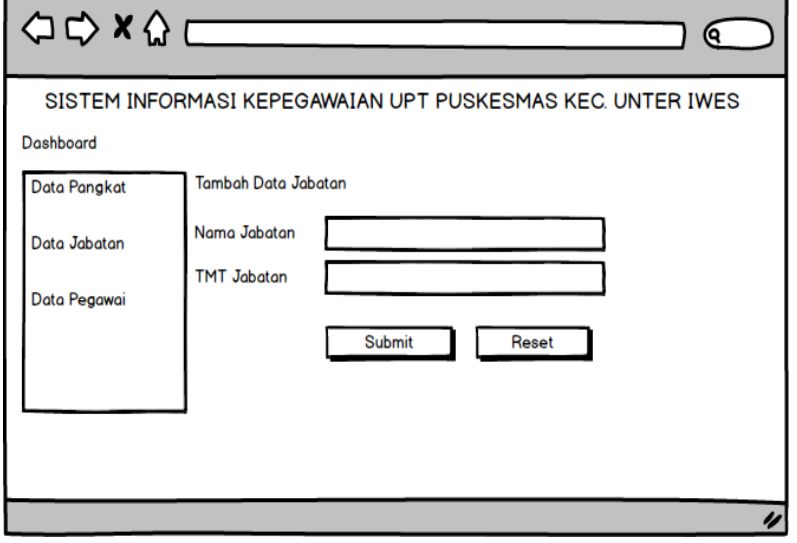

Gambar 3.11 Rancangan Tambah Data Jabatan

3. Code

Tahap mentrasformasikan design kedalam baris-baris program yaitu dengan membangun basisdata MySQL dengan menggunakan XAMPP,editor untuk membantu pengkodean dengan bahasa pemrograman PHP (Hypertext Preprocessor) mengggunakan Sublime Text.

4. Test

Setelah pengkodean selanjutnya implementasi dari Sistem Informasi Kepegawaian berbasis Web di UPT Puskesmas Kecamatan Unter Iwes, yaitu :

Implementasi Program

Adapun implementasi Sistem Informasi Kepegawaian berbasis Web di UPT Puskesmas Kecamatan Unter Iwes adalah sebagai berikut:

a. Tampilan Halaman Login Admin

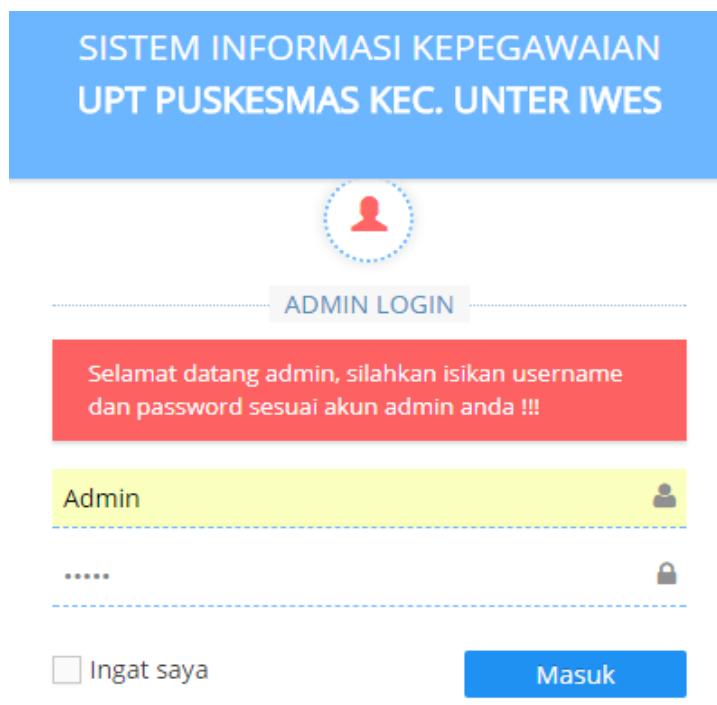

Gambar 3.12 Halaman Login Admin 
Pada Halaman Login Admin, admin harus memasukan terlebih dahulu username dan password untuk dapat mengakses Sistem Informasi Kepegawaian, hal tersebut sebagai bentuk keamanan penggunaan Sistem Informasi.

b. Tampilan Halaman Dashboard

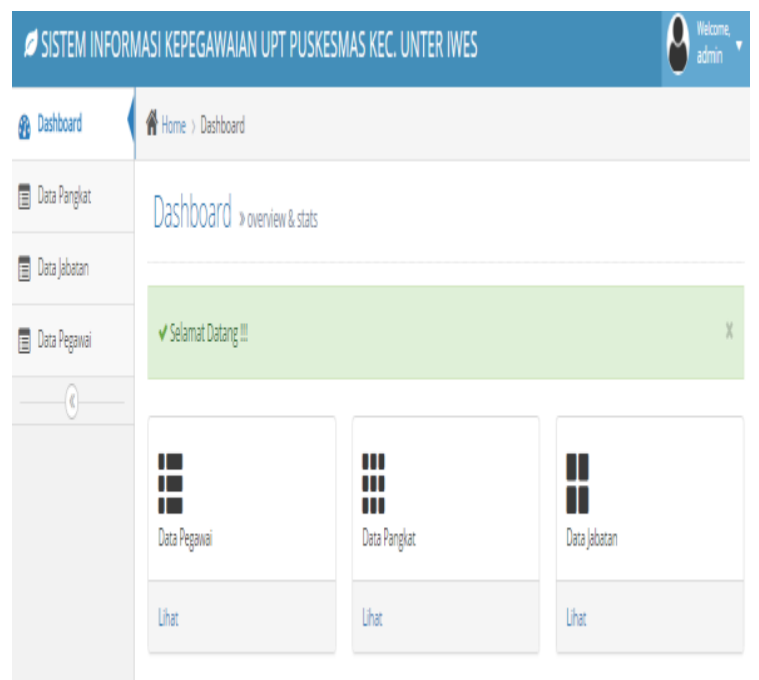

Gambar 3.13 Halaman Dashboard

Tampilan Dashboard ini merupakan halaman pertama yang muncul ketika admin melakukan login dengan benar.Pada halaman ini menampilkan beberapa menu-menu diantaranya dapat mengakses data pegawai, data pangkat dan data jabatan.Selain dapat mengakses data pegawai tersebut admin bisa mengelola data pegawai yang ada di dalam Sistem Informasi Kepegawaian.

\section{c. Tampilan Halaman Tabel Data Pegawai}

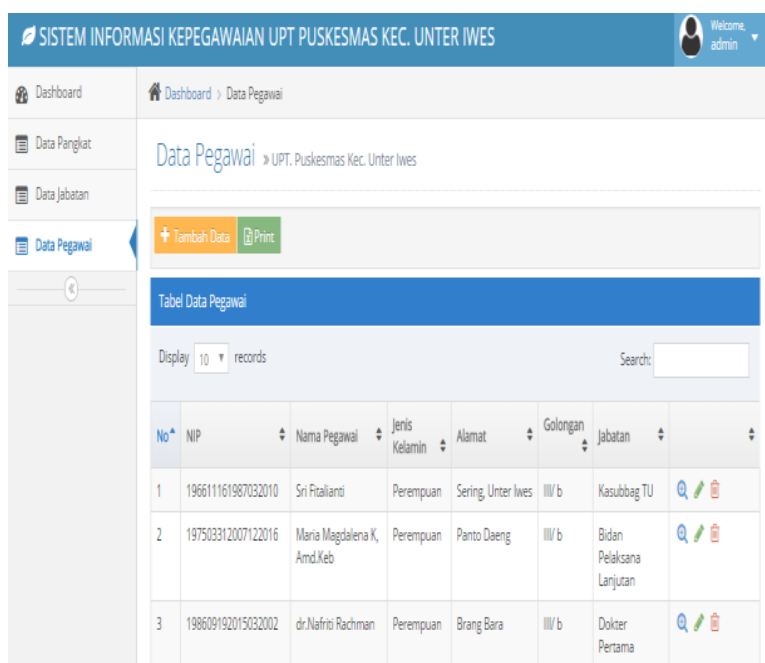

Gambar 3. 14 Halaman Tabel Data Pegawai
Tampilan tabel data pegawai terdapat tabel NIP, nama pegawai, jenis kelamin, alamat, golongan, jabatan. Tabel yang akan berisi biodata pegawai di UPT Puskesmas Kecamatan Unter Iwes.

\section{d. Tampilan Halaman Tambah Data Pegawai}

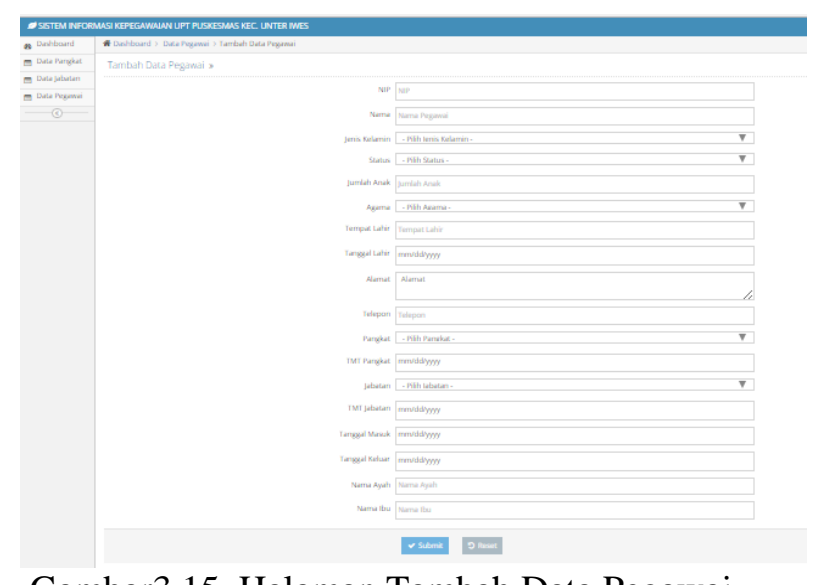

Gambar3.15 Halaman Tambah Data Pegawai

Tampilan halamantambah data pegawai yaitu berisi tentang biodata pegawai yang digunakan untuk melakukan penginputan data pegawai, dimana data pegawai akan diperlukan dan data pegawai akan diisi oleh admin sesuai dengan data pegawai yang asli. Data pegawai ini berkaitan dengan semua data pegawai baik itu mengenai data pangkat dan data jabatan.

\section{e. Tampilan Halaman Tabel Data Pangkat}

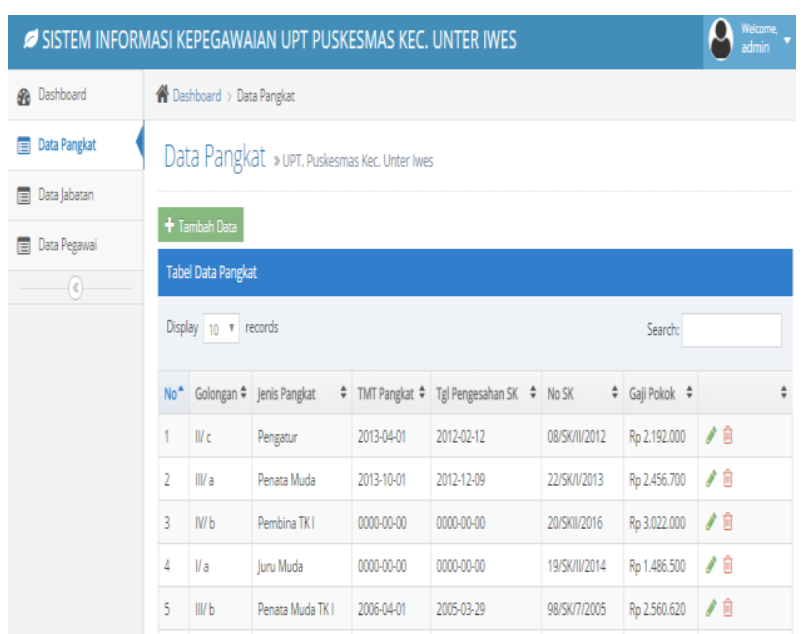

Gambar 3.16 Halaman Tabel Data Pangkat

Tampilan data pangkat yaitu akan menampilkan data pangkat yang telah diisi sesuai oleh admin. Tabel data pangkat berisi golongan dari pegawai, jenis pangkat, TMT 
pangkat, tanggal pengesahan SK, No SK dan gaji. Golongan pangkat dari pegawai akan menyesuaikan berapa besar gaji yang akan di terima oleh pegawai.

f. Tampilan Halaman Tambah Data Pangkat OSISTEM INFORMASI KEPEGAWAAN UPT PUSKESMAS KEC. UNTER IWES

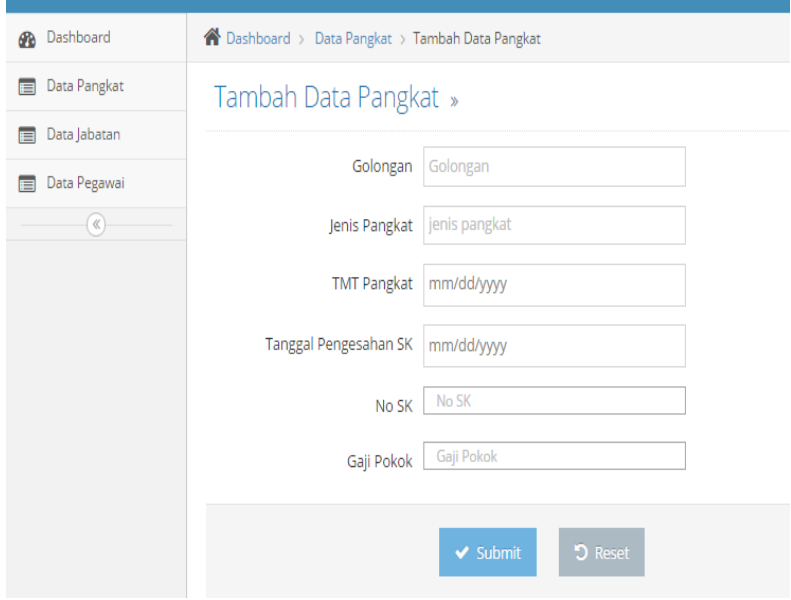

Gambar 3.17 Halaman Tambah Data Pangkat

Data pangkat di gunakan untuk melakukan penginputan golongan dari pegawai, dimana data pangkat pegawai akan diperlukan jika datadi isi oleh admin sesuai dengan data pangkat yang asli.

\section{g. Tampilan Halaman Tabel Data Jabatan}

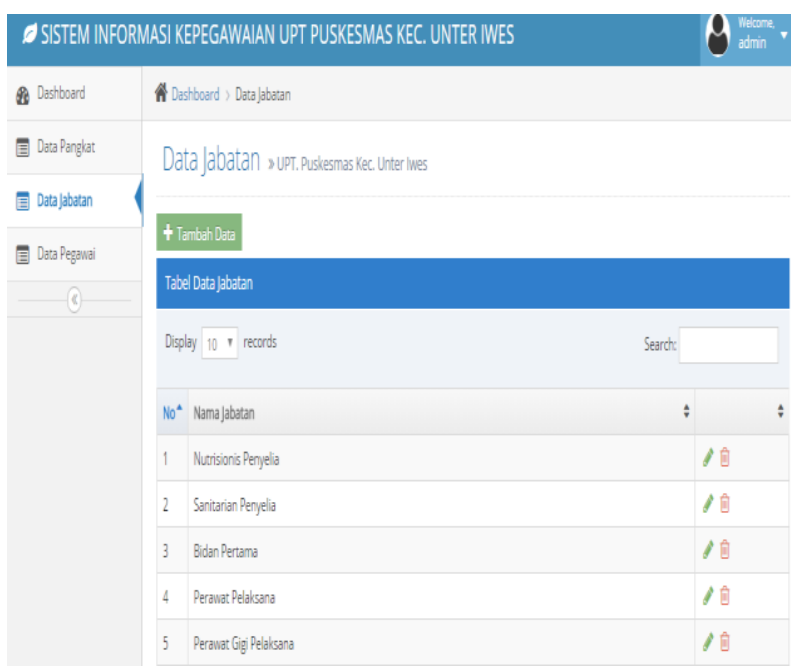

Gambar 3.18 Halaman Tabel Data Jabatan

Tabel ini berisi nama jabatan dari pegawai yang ada di UPT Puskesmas Kecamatan Unter Iwes.

h. Tampilan Halaman Tambah Data Jabatan
SISTEM INFORMASI KEPEGAWAIAN UPT PUSKESMAS KEC. UNTER IWES

(1) Dashboort

Â Dashboard > Data abatan > Tamboh Data Jabatan

国 Data Pangkat

Tambah Data Jabatan *

国 Data Jabatan

国 Data Pegawa

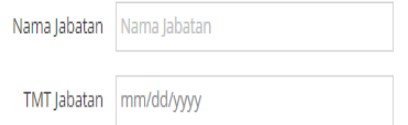

$\checkmark$ submi

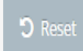

Gambar 3.19 Halaman Tambah Data Jabatan

Data jabatan di gunakan untuk melakukan penginputan nama jabatan dan TMT jabatan dari pegawai, dimana data jabatan pegawai akan diperlukan jika form ini di isi oleh admin sesuai dengan data jabatan yang asli.

Pengujian Perangkat Lunak

Berikut ini adalah hasil pengujian Sistem Informasi menggunakan metode pengujian black box:

a. Pengujian Login

Adapun hasil pengujian dari Login Admin Sistem Informasi Kepegawaian dapat dilihat pada tabel dibawah ini:

Tabel 3.10 Pengujian Login Admin

\begin{tabular}{|l|l|l|l|}
\hline \multicolumn{5}{|c|}{ Kasus dan Hasil Uji (Data Normal) } \\
\hline \multicolumn{1}{|c|}{ Yata masukg diharapkan } & \multicolumn{1}{|c|}{ pengamatan } & Kesimpulan \\
\hline $\begin{array}{l}\text { Username: } \\
\text { Admin } \\
\text { Password: } \\
\text { Admin }\end{array}$ & $\begin{array}{l}\text { Muncul menu utama } \\
\text { sesuai hak akses } \\
\text { Admin }\end{array}$ & $\begin{array}{l}\text { Muncul menu } \\
\text { utama admin }\end{array}$ & Diterima \\
\hline \multicolumn{4}{|c|}{ Kasus dan Hasil Uji (Data Tidak Normal) } \\
\hline Data Masukan & \multicolumn{1}{|c|}{ Yang diharapkan } & \multicolumn{1}{|c|}{ Pengamatan } & Kesimpulan \\
\hline Data Kosong & Muncul Resan & & \\
\hline $\begin{array}{l}\text { Data Salah } \\
\text { Contoh: } \\
\text { Username: }\end{array}$ & $\begin{array}{l}\text { Kedua field akan } \\
\text { dikosongkan. }\end{array}$ & $\begin{array}{l}\text { Hasil sesuai } \\
\text { dengan yang } \\
\text { diharapkan }\end{array}$ & Diterima \\
Password: & & & \\
12345 & & & \\
\hline
\end{tabular}

b. Pengujian Data Pegawai

Adapun hasil pengujian dari tambah data pegawai Sistem Informasi Kepegawaian dapat dilihat pada tabel dibawah ini:

Tabel 3.11 Pengujian Tambah Data pegawai 


\begin{tabular}{|c|c|c|c|}
\hline \multicolumn{4}{|c|}{ Kasus dan Hasil Uji (Data Normal) } \\
\hline Data Masulan & Yang diharapkan & Pengamatan & Kesimpulan \\
\hline 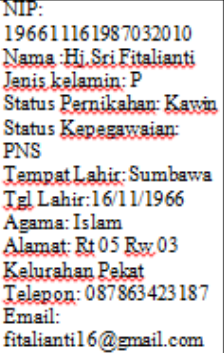 & $\begin{array}{l}\text { Data Mlasuls be tabel } \\
\text { data pegaxsi dan } \\
\text { muncul } \\
\text { pesan"Berhasil" }\end{array}$ & $\begin{array}{l}\text { Data Mlasuk ke } \\
\text { tabel data } \\
\text { pegawsidan. } \\
\text { muncul } \\
\text { pesan"Barhasil" }\end{array}$ & Diterimg \\
\hline \multicolumn{4}{|c|}{ Kasus dan Hasil Uji (Data Tidak Normal) } \\
\hline Data Masulkan & Yang diharapkan & Rengamatan & Kesimpulan \\
\hline 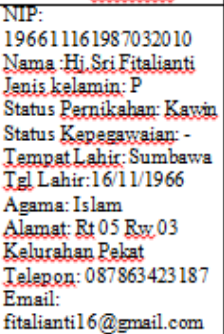 & $\begin{array}{l}\text { Muncul pesan " hards } \\
\text { dipilih" dibawah } \\
\text { sembebex status } \\
\text { Kepegarxaian. }\end{array}$ & $\begin{array}{l}\text { Duncul pesan } \\
\text { "harus dipilih" } \\
\text { dibawgh } \\
\text { sombebex status } \\
\text { Kepegarxaian }\end{array}$ & Diterima \\
\hline
\end{tabular}

c. Tabel Pengujian Data Pangkat

Adapun hasil pengujian dari tambah data pangkat Sistem Informasi Kepegawaian dapat dilihat pada tabel dibawahini:

Tabel 3.12 Pengujian Tambah Data Pangkat

\begin{tabular}{|c|c|c|c|c|}
\hline \multicolumn{5}{|c|}{ Kasus dan Hasil Uji (Data Normal) } \\
\hline Data masukan & & Yang diharapka & pengamatan & Kesimpulan \\
\hline $\begin{array}{l}\text { Golongan : IV/a } \\
\text { Jenis Pangkat : Pem } \\
\text { TMT Pangkat : } 10-0 \\
2014 \\
\text { Tgl Pengesahan SK } \\
10-2014 \\
\text { No SK : } 10 / \text { SK I/20 } \\
\text { Gapok :2.899.000 }\end{array}$ & & $\begin{array}{l}\text { Data masulk ke } \\
\text { tabel pangkat da } \\
\text { muncul pesan } \\
\text { "Berhasil" }\end{array}$ & $\begin{array}{l}\text { Data masukke k } \\
\text { tabel pangkat } \\
\text { dan muncul } \\
\text { pesan "Berhasil" }\end{array}$ & Diterima \\
\hline \multicolumn{5}{|c|}{ Kasus dan Hasil Uji (Data Tidak Normal) } \\
\hline Data masukan & & g diharankan & Pengamatan & Kesimpulan \\
\hline $\begin{array}{l}\text { Golongan :- } \\
\text { Jenis Pangkat : } \\
\text { Pembina } \\
\text { TMT Pangkat: } \\
\text { 10-01-2014 } \\
\text { Tgl Pengesahan } \\
\text { SK : 09-10-2014 } \\
\text { No SK : } \\
\text { 10/SKI/2014 } \\
\text { Gapok:2.899.000 }\end{array}$ & & $\begin{array}{l}\text { cul pesan } \\
\text { is dipilih" } \\
\text { wah Text Box }\end{array}$ & $\begin{array}{l}\text { Muncul pesan } \\
\text { "harus dipilih" } \\
\text { dibawah /Text Box }\end{array}$ & Diterima \\
\hline
\end{tabular}

d. Tabel Pengujian Data Jabatan

Adapun hasil pengujian dari tambah data jabatan Sistem Informasi Kepegawaian dapat dilihat pada tabel dibawah ini:

Tabel 3.13 Pengujian Tambah Data Jabatan Pegawai

\begin{tabular}{|c|c|c|c|}
\hline \multicolumn{4}{|c|}{ Kasus dan Hasil Uji (Data Normal) } \\
\hline Data masukan & Yang diharapkan & pengamatan & Kesimpulan \\
\hline $\begin{array}{l}\text { Pegawai : Hi.Siti } \\
\text { Fitalianti } \\
\text { Jabatan : Kepala } \\
\text { Subbag TU } \\
\text { TMT Jabatan : } 17 \\
\text { Maret } 2016\end{array}$ & $\begin{array}{l}\text { Data masuk ke table } \\
\text { jabatan dan muncul } \\
\text { pesan "Berhasil" }\end{array}$ & $\begin{array}{l}\text { Data masuk ke } \\
\text { table jabtan dan } \\
\text { muncul pesan } \\
\text { "Berhasil" }\end{array}$ & Diterima \\
\hline \multicolumn{4}{|c|}{ Kasus dan Hasil Uji (Data Tidak Normal) } \\
\hline Data masukan & Yang diharapkan & Pengamatan & Kesimpulan \\
\hline $\begin{array}{l}\text { Pegawai : Hj.Siti } \\
\text { Fitalianti } \\
\text { Jabatan: - } \\
\text { TMT Jabatan : } 17 \\
\text { Maret 2016 }\end{array}$ & $\begin{array}{l}\text { Muncul pesan } \\
\text { "harus dipilih" } \\
\text { dibawah Text Box }\end{array}$ & $\begin{array}{l}\text { Muncul pesan } \\
\text { "harus dipilih" } \\
\text { dibawah Text } \\
\text { Box }\end{array}$ & Diterima \\
\hline
\end{tabular}

\section{KESIMPULAN DAN SARAN KESIMPULAN}

Kesimpulan yang bisa diambil dari penelitian Sistem Informasi Kepegawaian Berbasis Web di UPT Puskesmas Kecamatan Unter Iwes sudah berhasil dibuat dengan menggunakan bahasa pemrograman PHP (Hypertext preprocessor) dan database MySQL. Sistem Informasi Kepegawaian ini terdapat data pribadi pegawai, data pangkat dan data jabatan. Sistem informasi kepegawaian ini bisa di akses oleh pegawai UPT Puskesmas Kecamatan Unter Iwes untuk memperoleh informasi mengenai pegawainya. Sistem Informasi Kepegawaian ini juga dapat memudahkan admin bagian administrasi kepegawaian dalam menginput data yang menyangkut dengan pengelolahan data pegawai

\section{SARAN}

Berdasarkan kesimpulan yang telah di uraikan diatas, maka diperlukan adanya pengembangan pada Sistem Informasi Kepegawaian yaitu terintegrasi pada data kepegawaian di Dinas kesehatan dan Dinas Kepegawaian Kabupaten Sumbawa.

\section{REFERENSI}

Abdullah, Dahlan. (2014)." Perancangan Sistem Informasi Pengolahan Data Pegawai Berbasis Web Di Setdakab Aceh Utara".Jurnal Penelitian Teknik Informatika, Vol.4 No.1, hlm 3. Tanggal Akses : 5 Juni 2017.

Ilham Madjid, Putra. (2011). “ Implementasi Sistem Informasi Manajemen Kepegawaian (SIMPEG) Pada Badan Kependudukan dan Keluarga Berencana Nasional". Skripsi. Depok: Jurusan Ilmu 
Administrasi Negara Universitas Indonesia.

Nur, Nia \& Tantri. (2010). “ Sistem Informasi Kepegawaian Berbasis Web Pada Balai Besar Teknologi Energi B2TE) Balai Pengkajian Penerapan Teknologi (BPPT) Serpong". Jurnal Seminar Nasional
Pengaplikasian Telematika Sinaptika, ISSN. 2086-8251, hlm.3.Tanggal Akses 14 Mei 2017.

Nurbaity, Siti. (2010). "Pengembangan sistem Informasi Kepegawaian (SIMPEG) Berbasis WEB" . Skripsi. Jakarta. Jurusan Teknik Informatika Universitas Islam Negeri Syarif Hidayatullah . 